\title{
The helminth fauna of brown trout (Salmo trutta) from a sub-alpine lake revisited after 40 years with introduced European minnow (Phoxinus phoxinus)
}

\author{
Reidar Borgstrom', Oyvind Hatleli Mestrand', John E. Brittain', Leif Lien
}

\begin{abstract}
Borgstrøm R, Hatleli Mestrand Ø, Brittain JE and Lien L. 2021. The helminth fauna of brown trout (Salmo trutta) from a sub-alpine lake revisited after 40 years with introduced European minnow (Phoxinus phoxinus). Fauna norvegica 41: 15-26.

The helminth fauna of brown trout (Salmo trutta) in the Norwegian subalpine lake, Øvre Heimdalsvatn was studied by examination of gills, eyes, body cavity, kidney, stomach, pyloric region and intestine in a total of 112 brown trout randomly sampled in June, July, and September 2011. Ten helminth species, Discocotyle sagittata, Phyllodistomum umblae, Crepidostomum farionis, C. metoecus, Diplostomum sp., Proteocephalus sp., Cyathocephalus truncatus, Dibothriocephalus ditremus, D. dendriticus, and Capillaria sp. were identified. These data were compared to data from the period 1969 to 1972, just after the first record of the European minnow (Phoxinus phoxinus) in 1969. All ten helminth species, except $D$. dendriticus, were also present in 1969-72. However, a few major changes in infection intensities have occurred. The cestode $D$. ditremus and the trematode Diplostomum sp., both with piscivorous birds as final hosts, had markedly higher relative densities (abundance) in brown trout in 2011 compared to 1969-72, while the two Crepidostomum species showed a substantial decline in relative densities. We suggest that these changes may be indirectly related to the establishment and subsequent population increase of European minnow in the lake. The abundance of minnows may have increased the food basis for the piscivorous birds, primarily mergansers and the black-throated diver that now regularly forage in the lake. In addition, there have been changes in the littoral invertebrate community, including species serving as intermediate hosts of some of the brown trout parasites.
\end{abstract}

doi: 10.5324/fn.v4li0.3952. Received: 2021-01-21. Accepted: 2021-03-23. Published online: 2021-05-27. ISSN: 1891-5396 (electronic).

Keywords: parasite fauna, parasite abundance, fish, long-term changes, invasive species, mountain lake

1. Faculty of Environmental Sciences and Natural Resource Management, Norwegian University of Life Sciences, PO Box 5003 NMBU, NO-1432 As, Norway

2. Natural History Museum, University of Oslo, PO Box 1172 Blindern, NO-0318 Oslo, Norway

3. Vollsveien 62, NO-1358 Jar, Norway

Corresponding author: Reidar Borgstrøm

E-mail: reidar.borgstrom@nmbu.no

\section{INTRODUCTION}

Fish may serve as both intermediate and final hosts of helminth species which have developed a variety of life history strategies, from complex life cycles with several intermediate hosts to direct cycles without intermediate hosts (Moravec 1994; Margoliese 1995; Hoffman 1999; Amundsen et al. 2003). Accordingly, environmental changes as well as changes in abundance of both intermediate and final hosts may all influence the parasite burden in a fish population.

During the last hundred years there has been a worldwide spread of exotic freshwater fish and invertebrate species (Esch et al. 1988; Welcomme 1988; Hall \& Mills 2000). Such introductions may result in substantial changes in the parasite fauna and infection patterns of indigenous fish species (Gozlan et al. 2005). In Norway, the European minnow (Phoxinus phoxinus (Linnaeus, 1758)) has been spread by man to localities far outside its natural distribution area (Saltveit \& Brabrand 1991; Hesthagen \& Sandlund 1997). At present, this small cyprinid has become established in all Norwegian counties, with populations in several mountain lakes where brown trout (Salmo trutta Linnaeus, 1758) was previously the sole fish species (Museth et al. 2007). The benthic invertebrate community may be strongly influenced by the establishment of a European minnow population, as observed in the Norwegian subalpine lake, Øvre Heimdalsvatn (Næstad \& Brittain 2010). Despite extensive fishery studies in this lake since 1957 (Jensen 1977), the European minnow was only first recorded in 1969 (Larsson et al. 1978), and in the following years established a large population (Lien 1981; Museth et al. 2002). Young brown trout and European minnow share both the streams and the shallow littoral areas of the lake, and the overlapping habitat use and diet of these two species suggest a negative influence of the minnows on the trout population (Borgstrøm et al. 2010; Museth et al. 2010; Næstad \& Brittain 2010).

The summer diet of brown trout during the years 1969-1972 included a high proportion of Gammarus lacustris G. O. Sars, 1863 and Lepidurus arcticus (Pallas, 1793), while fish were never recorded 
as part of the diet (Lien 1978). However, L. arcticus has been almost absent in brown trout diet during the last decades (Borgstrøm et al. 2010), and G. lacustris has declined considerably in abundance in the shallow part of the littoral zone (Næstad \& Brittain 2010). Nevertheless, G. lacustris is still a common food item of brown trout (Borgstrøm et al. 2010). Minnows have become an important part of the trout diet, but also small brown trout are eaten by larger conspecifics (Borgstrøm et al. 2010).

The parasites of brown trout in the lake were first studied by monthly samples during the period December 1969 to December 1971, with some additional samples in 1972 (Lien 1976; 1978), i.e. during a period when European minnow still had a very low population density (Lien 1981). These data form a basis for evaluating possible long-term changes in the parasite fauna of brown trout in the lake, from 1969-72 to 2011. Brown trout serve as intermediate host for some of the helminth species recorded in 1969-72, with piscivorous birds as final hosts. Water temperature may be an important environmental factor, influencing development of parasite stages (Karvonen et al. 2010, 2013), and thereby affecting both prevalence and intensity of infection in brown trout. Thus, we hypothesise that environmental changes and changes in the invertebrate community, together with changes in dynamics of the fish populations and abundance of piscivorous birds, have influenced the helminth fauna of brown trout in the lake, Øvre Heimdalsvatn.

\section{MATERIAL AND METHODS}

\section{The lake Øvre Heimdalsvatn}

The subalpine lake, Øvre Heimdalsvatn is situated in southern
Norway (latitude $61^{\circ} 25^{\prime} 32^{\prime \prime}$ and longitude $8^{\circ} 52^{\prime} 10^{\prime \prime}$ ), at $1088 \mathrm{~m}$ a. s. 1., on the eastern slopes of the Jotunheimen Mountains (Figure 1). The lake is normally ice-covered from the end of October until early June (Kvambekk \& Melvold 2010). The surface area is $0.78 \mathrm{~km}^{2}$, with a maximum depth $13.0 \mathrm{~m}$, and an average depth $4.7 \mathrm{~m}$ (Grøterud \& Kloster 1978). Lake temperatures in Øvre Heimdalsvatn were measured continuously in 1970-72 (Kloster 1978), and from 1986 temperature in the outlet river (Hinøgla) has been measured daily at 11 a.m. (Sildre database; www.nve.no), but not in the lake itself. According to Kvambekk \& Melvold (2010) there is a significant correlation between air temperature at Skåbu meteorological station (www. seklima.met.no) and the outlet temperature of Øvre Heimdalsvatn during the months July - September. Data from Skåbu are available from 1969 to the end of 2009 (the station is now closed). The average June - August temperature at Skåbu shows a weak declining trend from 1969 to 2009, but with large annual variations, with 1997 as the warmest and 1993 as the coldest summers during this period (Figure 2). The average temperature for the summers (June - August) 1969-72 and 2006-2009 was 10.8 and $10.7^{\circ} \mathrm{C}$, respectively.

Øvre Heimdalsvatn is a reference lake for subalpine ecosystems, with long time series of physical, chemical and biological parameters (Brittain \& Borgstrøm 2010a, 2015; Brittain et al. 2019). The brown trout population studies commenced in 1957 (Jensen 1977), and at intervals they have continued until today (summarised in Brittain \& Borgstrøm 2015; Brittain et al. 2019). In 1957, the brown trout population was very dense $(>20 \mathrm{~kg} / \mathrm{ha})$, with high annual recruitment and early growth stagnation of individual fish. After extensive exploitation during the following years, few fish older than ten years were present, and with a marked increase in individual growth rates (Jensen 1977). Annual recruitment to the brown trout population has

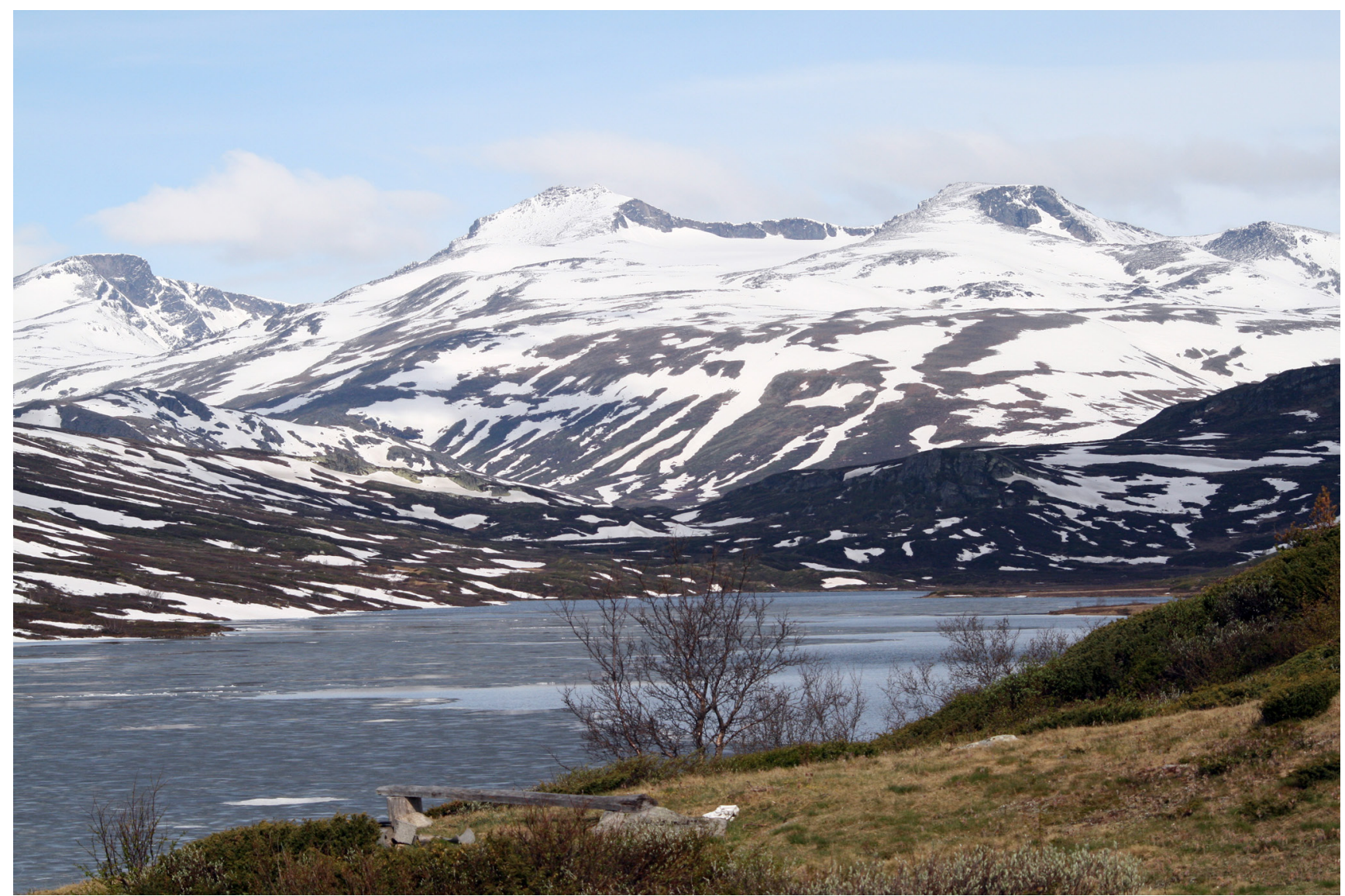

Figure I. The lake, Øvre Heimdalsvatn, $1088 \mathrm{~m}$ a. s. 1., still partly ice-covered on 12 June 2008. Some of the peaks of the Jotunheimen Mountains in the background. 


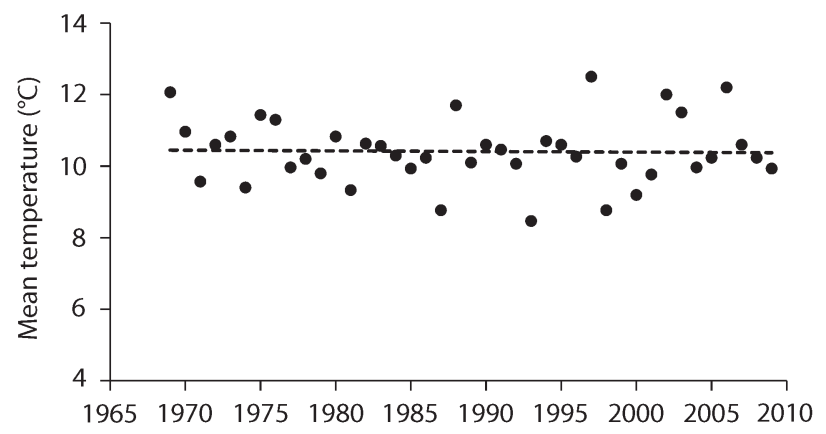

Figure 2. Mean air temperature for the months June - August at Skåbu meteorological station 1969-2009 (data from https://seklima.met.no).

been halved during the years 1993-2009 compared to the years 19631970 (Jensen 1977; Borgstrøm et al. 2010), but exploitation has been negligible, and total biomass has been in the same order compared to the years 1963-1970 (Jensen 1977; Brittain et al. 2019).

The benthic fauna and diet of brown trout was first investigated by the freshwater section of the Norwegian IBP (International Biological Programme) during the period 1969-72 (Vik 1978) and has been continued at irregular intervals since (see Brittain \& Borgstrøm 2010b; Brittain et al. 2019).

The number of fish-eating birds at the lake has also changed from the initial period, concomitant with the establishment of European minnow. In 1968-1972, the Common gull (Larus canus Linnaeus, 1758) together with the mergansers, Mergus merganser Linnaeus, 1758 and M. serrator Linnaeus, 1958, were observed, but they were not common (Lien \& Nydal 1973). During the 1990s and up until the present study in 2011, three to five females of $M$. merganser and $M$. serrator have been feeding and nesting in close proximity to the lake (Jan T. Lifjeld pers. comm., and own observations). The black-throated diver (Gavia arctica (Linnaeus, 1758)) has also been regularly foraging there in these years (Jan T. Lifjeld, pers. comm., and own observations), while only two observations were made during the years 1968-72 (Lien \& Nydal 1973). Likewise, grey heron (Ardea cinerea Linnaeus, 1758) has been observed regularly (own observations) but was not recorded by Lien \& Nydal (1973). Observations of Arctic tern
(Sterna paradisaea Pontoppidan, 1793) have increased, with one to three individuals foraging in the lake, in addition to about five nesting pairs of the Common gull (Jan T. Lifjeld pers. comm.).

A total number of 330 brown trout captured by gillnetting with various mesh sizes all over the lake during the years 1969-72 were quantitatively examined for helminth parasites by Lien $(1976,1978)$, as part of the IBP on Øvre Heimdalsvatn. Ten trout were examined each month during the period December 1969 to December 1971, and 25 trout were examined in each of the months April, August, and December 1972. In this extensive sampling of parasites from brown trout, 10 helminth species were recorded (Lien 1976, 1978), of which brown trout is the final host of six species, and piscivorous birds of four species (Table 1). Invertebrates are included in the life history of all the species (Table 1), except Discocotyle sagittata (Leuckart, 1842) which has a direct life cycle. Results of the study by Lien (1976) have formed the basis for a comparison with results obtained in the present study in 2011.

\section{Sampling of brown trout and helminths}

Brown trout were sampled in June, July and September 2011 using a gillnet fleet consisting of gillnets with length of $25 \mathrm{~m}$ and $1.5 \mathrm{~m}$ in height, with the mesh sizes 16, 19.5, 22.5, 26, 29, 31, 35, 39, and 45mm (measured from knot to knot). The gillnets were set in the littoral zone all over the lake, similar to the study in 1969-72 (Lien 1976) to avoid any influence of habitat specific factors on sampling of both parasites and stomach contents of brown trout. Total length and weight of all captured fish were measured in $\mathrm{mm}$ and in gram, respectively, and otoliths and scales were sampled for age determination. To determine age, otoliths from fish below about $18 \mathrm{~cm}$ were studied directly after clearing in ethanol. Otoliths from larger fish were cut in half through the nucleus and burnt before reading the age (Power 1978). In a few cases, both otoliths were hyaline, and age was determined by using scales. Lien $(1976,1978)$ used scales for determination of brown trout age. In Øvre Heimdalsvatn, there is a full correspondence between otolith and scale age readings of brown trout up to around the age of eight - nine years (own data, unpublished), which means that data from the period 1969-72 regarding information concerning parasite infections in different age-classes are fully comparable to data from 2011.

Table I. Helminth species/genera described from brown trout in the lake Øvre Heimdalsvatn (Lien 1976, 1978), with an overview of species involved in their assumed life histories in the lake.

\begin{tabular}{|c|c|c|c|}
\hline Species/genus & Final host/organ & First intermediate host & Second intermediate host \\
\hline $\begin{array}{l}\text { Discocotyle sagittata (Leuckart 1842) } \\
\text { Diesing, } 1850\end{array}$ & Brown trout, gills & & \\
\hline $\begin{array}{l}\text { Phyllodistomum umblae (=conostomum) } \\
\text { (Fabricius, 1780) }\end{array}$ & Brown trout, kidney & $\begin{array}{l}\text { Bivalves (Sphaerium Scopoli, } 1777 \\
\text { and Pisidium Pfeiffer, 1821.) }\end{array}$ & \\
\hline $\begin{array}{l}\text { Crepidostomum metoecus (Braun, 1900) } \\
\text { and C. farionis (Müller, 1780) Lühe, } \\
1900\end{array}$ & Brown trout, intestine & $\begin{array}{l}\text { Bivalves (Pisidium spp., and snail, } \\
\text { Radix balthica (Linnaeus, 1758) }\end{array}$ & $\begin{array}{l}\text { Mayflies (Ephemeroptera), } \\
\text { Gammarus lacustris }\end{array}$ \\
\hline Diplostomum von Nordmann, 1832 & Piscivorous birds, intestine & Snail, Radix balthica & $\begin{array}{l}\text { Brown trout, European minnow, } \\
\text { in eyes }\end{array}$ \\
\hline Proteocephalus Weinland, 1858 & $\begin{array}{l}\text { Brown trout, intestine/ } \\
\text { pyloric caeca }\end{array}$ & Copepods (Cyclops Müller, 1776) & \\
\hline $\begin{array}{l}\text { Dibothriocephalus ditremus (Creplin, } \\
\text { 1825) Lühe, 1899, and D. dendriticus } \\
\text { (Nitzsch, 1824) Lühe, } 1899\end{array}$ & Piscivorous birds, intestine & Copepods (Cyclops spp.) & Brown trout, organs in body cavity \\
\hline Cyathocephalus truncatus (Pallas, 1781) & Brown trout, pyloric caeca & Gammarus lacustris & \\
\hline Capillaria Zeder, 1800 & Brown trout, intestine & Probably oligochaetes & \\
\hline Eustrongylides Jägerskiöld, 1909 & Piscivorous birds, intestine & Oligochaetes & $\begin{array}{l}\text { Brown trout, European minnow, in } \\
\text { body cavity }\end{array}$ \\
\hline
\end{tabular}


A total of 392 brown trout were caught, of which 112 were randomly picked for sampling of helminths from the organs, gills, eyes, kidney, stomach, pyloric region, intestine, and body cavity of the sampled fish. For collecting Proteocephalus Weinland, 1858 and Cyathocephalus truncatus (Pallas, 1781) which both have their scolex attached in the pylorus caeca, the pylorus region was opened, loose contents removed for examination of helminth individuals, and subsequently this part of the intestine was placed in water overnight to release individuals of the two cestodes. Examination and searching of the organs for helminth parasites is time consuming, and we had to take subsamples for specific species/organs even among the 112 individuals. Before a fish was selected for parasite examination, it was decided what organs that should be included. Based on the agelength relationship of brown trout from the lake, the examined fish were collected to ensure sampling from a range of age and length classes. The sampled helminths from each examined brown trout were counted and preserved in ethanol. In total, brown trout with age from 3 to 15 winters are included in the study (Table 2). Due to the stagnation in annual growth in length after maturation, the differences in mean length of the age-classes $\geq 8$ winters are small (Table 2), as also shown in Solhaug et al. (2010). Therefore, we sampled a relatively high number of fish in the length range 30.0-39.9 cm to ensure that several age-classes were represented with at least some individuals. Lien (1976) presented the relative density (abundance) of parasite species recorded (wrongly stated as infection intensities) in the ageclasses 3-4, 5, 6, and $\geq 7$ winter old brown trout from the lake Øvre Heimdalsvatn, and to make a comparison with his results, we have used the same age categories in the summary statistics.

The trout stomach and oesophagus contents of the individuals examined for parasites were preserved in ethanol for subsequent dietary analysis in the laboratory. The volume percent of the different prey item categories in each stomach was recorded according to Hynes (1950).

\section{Parasite identification}

The parasites sampled in 2011 were identified to species or genus, and counted under a stereomicroscope, used both in the field laboratory and in the laboratory of the Natural History Museum, University of Oslo. Crepidostomum farionis (Müller, 1784) and C. metoecus (Braun, 1900) were identified and separated by morphology, according to Moravec (2002), and Phyllodistomum umblae (Fabricius, 1780) was identified by use of description given by Bakke (1984). This species $(P$. conostomum $=P$. umblae $)$ was also identified previously by Bakke \& Lien (1978) from brown trout in the lake, Øvre Heimdalsvatn. The plerocercoids of Dibothriocephalus Lühe, 1899 (formerly Diphyllobothrium Cobbold, 1858, see Waeschenback et al. 2017) were identified to $D$. ditremus (Creplin, 1825) Lühe, 1899, and D. dendriticus (Nitzsch, 1824) Lühe, 1899 using descriptions in Vik (1964), Halvorsen (1970), and Andersen and Gibson (1989), while the other helminth species were identified either to genus or species using Bykhovskaya-Pavlovskaya et al. (1964).

\section{Statistical analysis}

The parasite counts were recorded in Excel spreadsheets and used to compute mean and median intensity, prevalence, and relative density (or abundance, i.e., mean number of individuals of a particular parasite species per host examined), all according to Margolis et al. (1982). In addition, linear regression of relative density of each parasite species in age and length-classes of brown trout were computed.

\section{RESULTS}

\section{Intermediate hosts in brown trout diet}

The brown trout diet in 2011 varied both seasonally and with fish size (Figure 3). Bivalves (Pisidium sp.) i.e., first intermediate host in the life history of P. umblae and Crepidomum spp., had a low occurrence in diet of brown trout, and made up a small volume percent of the stomach contents. Likewise, mayflies contributed a low volume percent in the diet, except in the largest length-class in July. Radix balthica (Linnaeus, 1758), was relatively common in the diet, although contributing a low volume percent of the stomach contents. G. lacustris, the intermediate host of $C$. truncatus, and possibly an intermediate host of Crepidostomum spp., made up a relatively large volume percent in the length-classes 20-29.9 and 30-39.9 cm. Copepods, serving as intermediate hosts for Proteocephalus sp. and Dibothriocephalus spp., were found in one stomach only, in September. European minnow had been eaten by a few trout in the length-classes $>20 \mathrm{~cm}$ (Figure 3).

Prey groups not functioning as intermediate hosts for the brown trout helminths, such as chironomids, other aquatic insects, and terrestrial insects, constituted a large part of the brown trout summer diet, together with cladocerans. Lepidurus arcticus was present but was found only in a single brown trout in July.

\section{The helminth parasite fauna}

Ten helminth species were found in the samples in June, July and September 2011 (Table 3), and of those, nine were also present in 1969-1972 (Table 1). The most numerous parasite taxon in 2011 was Diplostomum sp., followed by Crepidostomum metoecus (Table 3).

\section{Dibothriocephalus spp.}

The prevalence of $D$. ditremus varied from a minimum of $22.2 \%$ in age-class 5 to a maximum of $60.9 \%$ in age-class $7-8$ winters, and except for age-class 3-4, the mean and median infection intensities were relatively high in all age-classes (Table 3). The highest numbers of larvae were found in two 15 winter-old fish, with respectively 89 and 297 plerocercoids. Despite the over-dispersion of larvae, the relative density increased significantly with age (linear regression: $\mathrm{R}^{2}=0.76$, $\mathrm{df}=6, \mathrm{~F}=16.02, \mathrm{p}<0.05$ ), while the linear regression between relative density and length-class was not significant $\left(\mathrm{R}^{2}=0.52, \mathrm{df}=5, \mathrm{~F}=4.40\right.$, $\mathrm{p}>0.05$ ), due to the very much higher relative density in length-class 35-39.9 cm (Figure 4). A single specimen of D. dendriticus was identified as a new species in the lake (Table 3).

Table 2. Number and average length $(\mathrm{cm})$ of brown trout in age-class 3-15 winters from the lake Øvre Heimdalsvatn sampled for parasites and stomach contents, in June, July, and September 2011.

\begin{tabular}{|c|c|c|c|c|c|c|c|c|c|c|c|c|c|}
\hline & \multicolumn{13}{|c|}{ Age-class (winters) } \\
\hline & 3 & 4 & 5 & 6 & 7 & 8 & 9 & 10 & 11 & 12 & 13 & 14 & 15 \\
\hline Number examined & 10 & 12 & 16 & 15 & 8 & 15 & 13 & 5 & 8 & 4 & 1 & 3 & 2 \\
\hline Mean length (cm) & 15.1 & 15.0 & 20.8 & 23.1 & 27.6 & 31.0 & 32.3 & 32.3 & 32.8 & 33.8 & 34.1 & 35.0 & 38.7 \\
\hline
\end{tabular}


Table 3. Mean (Mea.) and median (Med.) intensity, and prevalence (Prev.) of helminths sampled from different age-classes of brown trout in the lake Øvre Heimdalsvatn, as an average for the months June, July, and September 2011.

\begin{tabular}{|c|c|c|c|c|c|c|c|c|c|c|c|c|c|c|c|c|c|c|}
\hline \multirow[b]{4}{*}{ Parasite species } & \multicolumn{18}{|c|}{ Age-class (winters) } \\
\hline & \multicolumn{3}{|c|}{$3-4$} & \multicolumn{3}{|c|}{5} & \multicolumn{3}{|c|}{6} & \multicolumn{3}{|c|}{$7-8$} & \multicolumn{3}{|c|}{$9-10$} & \multicolumn{3}{|c|}{$11-15$} \\
\hline & \multicolumn{2}{|c|}{ Intensity } & \multirow[b]{2}{*}{ Prev. } & \multicolumn{2}{|c|}{ Intensity } & \multirow[b]{2}{*}{ Prev. } & \multicolumn{2}{|c|}{ Intensity } & \multirow[b]{2}{*}{ Prev. } & \multicolumn{2}{|c|}{ Intensity } & \multirow[b]{2}{*}{ Prev. } & \multicolumn{2}{|c|}{ Intensity } & \multirow[b]{2}{*}{ Prev. } & \multicolumn{2}{|c|}{ Intensity } & \multirow[b]{2}{*}{ Prev. } \\
\hline & Mea. & Med. & & Mea. & Med. & & Mea. & Med. & & Mea. & Med. & & Mea. & Med. & & Mea. & Med. & \\
\hline $\begin{array}{l}\text { Discocotyle } \\
\text { sagittata }\end{array}$ & 1.7 & 1.0 & 35.3 & 3.4 & 2.0 & 77.8 & 6.2 & 6.0 & 90.9 & 6.1 & 7.0 & 82.4 & 8.5 & 5.0 & 84.6 & 8.8 & 5.5 & 100 \\
\hline $\begin{array}{l}\text { Phyllodistomum } \\
\text { umblae }\end{array}$ & 2.2 & 2.0 & 27.8 & 5.2 & 3.5 & 100 & 10.3 & 10.0 & 90.0 & 7.6 & 6.0 & 81.3 & 8.5 & 4.5 & 60.0 & 4.3 & 2.0 & 70.0 \\
\hline $\begin{array}{l}\text { Crepidostomum } \\
\text { farionis }\end{array}$ & 2.0 & 2.0 & 25.0 & 3.0 & 3.0 & 16.7 & 3.0 & 3.0 & 50.0 & 2.8 & 3.0 & 38.5 & 3.4 & 3.0 & 100 & 1.7 & 1.0 & 37.5 \\
\hline $\begin{array}{l}\text { Crepidostomum } \\
\text { metoecus }\end{array}$ & 10.7 & 5.0 & 100 & 16.2 & 14.5 & 100 & 17.4 & 8.0 & 100 & 21.3 & 20.0 & 100 & 27.8 & 15.0 & 100 & 29.4 & 21.5 & 100 \\
\hline Diplostomum sp. & 17.3 & 12.0 & 88.2 & 59.6 & 49.0 & 100 & 54.8 & 54.5 & 100 & 60.4 & 55.5 & 100 & 66.7 & 55.0 & 100 & 111.7 & 86.0 & 100 \\
\hline Proteocephalus sp. & 1.0 & 1.0 & 5.9 & 0.0 & 0.0 & 0.0 & 3.0 & 3.0 & 18.2 & 3.3 & 3.0 & 17.6 & 1.5 & 1.5 & 15.4 & 11.5 & 11.5 & 16.7 \\
\hline $\begin{array}{l}\text { Cyathocephalus } \\
\text { truncatus }\end{array}$ & 1.3 & 1.0 & 23.5 & 1.7 & 2.0 & 33.3 & 3.5 & 3.0 & 33.3 & 4.6 & 2.0 & 47.1 & 1.4 & 1.0 & 38.5 & 6.0 & 3.0 & 58.3 \\
\hline $\begin{array}{l}\text { Dibothriocephalus } \\
\text { ditremus }\end{array}$ & 1.8 & 2.0 & 29.4 & 18.5 & 18.5 & 22.2 & 11.0 & 8.0 & 27.3 & 23.3 & 7.0 & 60.9 & 10.0 & 5.0 & 44.4 & 44.4 & 2.0 & 50.0 \\
\hline $\begin{array}{l}\text { Dibothriocephalus } \\
\text { dendriticus }\end{array}$ & 0.0 & 0.0 & 0.0 & 0.0 & 0.0 & 0.0 & 0.0 & 0.0 & 0.0 & 0.0 & 0.0 & 0.0 & 0.0 & 0.0 & 0.0 & 1.0 & 1.0 & 5.60 \\
\hline Capillaria sp. & 1.0 & 1.0 & 17.6 & 2.0 & 2.0 & 42.9 & 2.8 & 2.5 & 33.3 & 2.7 & 2.0 & 50.0 & 1.7 & 2.0 & 42.9 & 3.5 & 3.5 & 20.0 \\
\hline
\end{tabular}
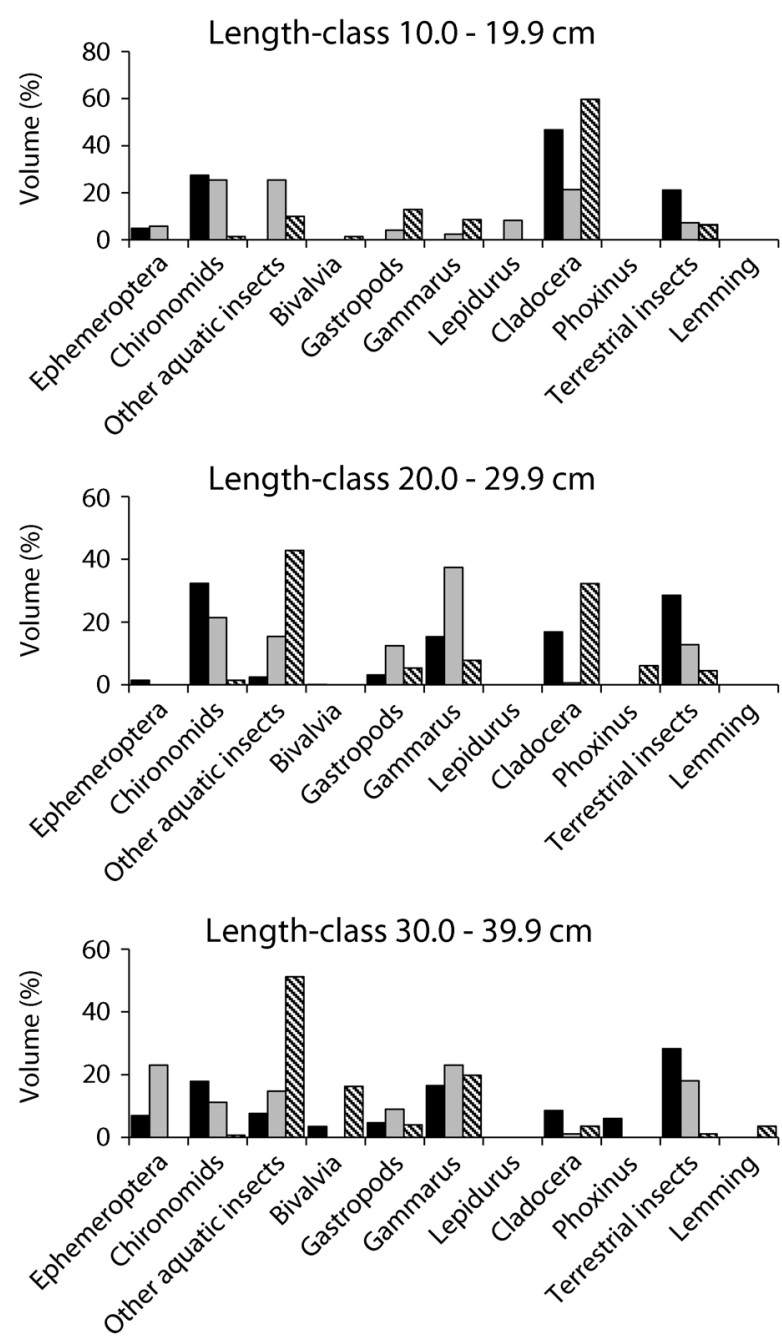

Figure 3. Stomach content composition (volume \%) of brown trout in the length-classes 10-19.9, 20.0-29.9, and 30.0-39.9 cm (almost corresponding to the age-classes $3-4,5-7$, and 8-15 winters, respectively), from the lake, Øvre Heimdalsvatn, sampled in June (black), July (grey) and September (patterned) 2011.

\section{Cyathocephalus truncatus}

The mean and median intensity of infection with $C$. truncatus was low in 2011, with a prevalence varying from $23.5 \%$ in age-class 3-4 to a maximum of $58.3 \%$ in age-class $11-15$ winters (Table 3). There was a significant linear relationship between age-classes and the relative density of $C$. truncatus (linear regression, age: $\mathrm{R}^{2}=0.69$, $\mathrm{df}=6, \mathrm{~F}=11.15, \mathrm{p}<0.05$ ), and correspondingly between length-classes and relative density (linear regression; $\mathrm{R}^{2}=0.71, \mathrm{df}=5, \mathrm{~F}=9.65, \mathrm{p}<0.05$ ) (Figure 4). The positive relationship between relative volume of $G$. lacustris in stomach contents of brown trout age-classes 3 to $\geq 9$ winters and the relative density of $C$. truncatus was also significant (linear regression; $\mathrm{R}^{2}=0.82, \mathrm{df}=6, \mathrm{~F}=23.26, \mathrm{p}<0.01$ ) (Figure 5).

\section{Proteocephalus sp}

Proteocephalus sp. was primarily found in June, with only one specimen observed in July and none in September. The mean and median intensity of infection was low in all age-classes, as was the prevalence (Table 3).

\section{Crepidostomum spp}

C. metoecus was recorded in all examined trout and had a high mean and median intensity compared to $C$. farionis, which also had a much lower prevalence in all age-classes (Table 3). The positive relationships between age-classes/length-classes, respectively, and relative density of Crepidostomum spp. were both significant (linear regression, age: $\mathrm{R}^{2}=0.88, \mathrm{df}=6, \mathrm{~F}=37.21, \mathrm{p}<0.01$; length: $\mathrm{R}^{2}=0.66, \mathrm{df}=5, \mathrm{~F}=7.83, \mathrm{p}<0.05$ ) (Figure 6). There was no significant relationship between the relative volume of $G$. lacustris in stomach contents and relative density of $C$. metoecus in the age-classes $3-\geq 9$ winters $\left(\mathrm{R}^{2}=0.34, \mathrm{df}=6, \mathrm{~F}=2.62\right.$, $\mathrm{p}>0.05)$. Neither was there a significant relationship between relative volume percent of G. lacustris + mayflies in stomach contents (both expected intermediate hosts) and relative density of Crepidostomum spp. in age-class $3-\geq 9$ winters $\left(R^{2}=0.54, d f=6, F=6.02, p>0.05\right)$.

\section{Diplostomum sp.}

Diplostomum sp. had a high mean and median intensity, and with a $100 \%$ prevalence in all age-classes $\geq 5$ winters (Table 3 ). The positive 

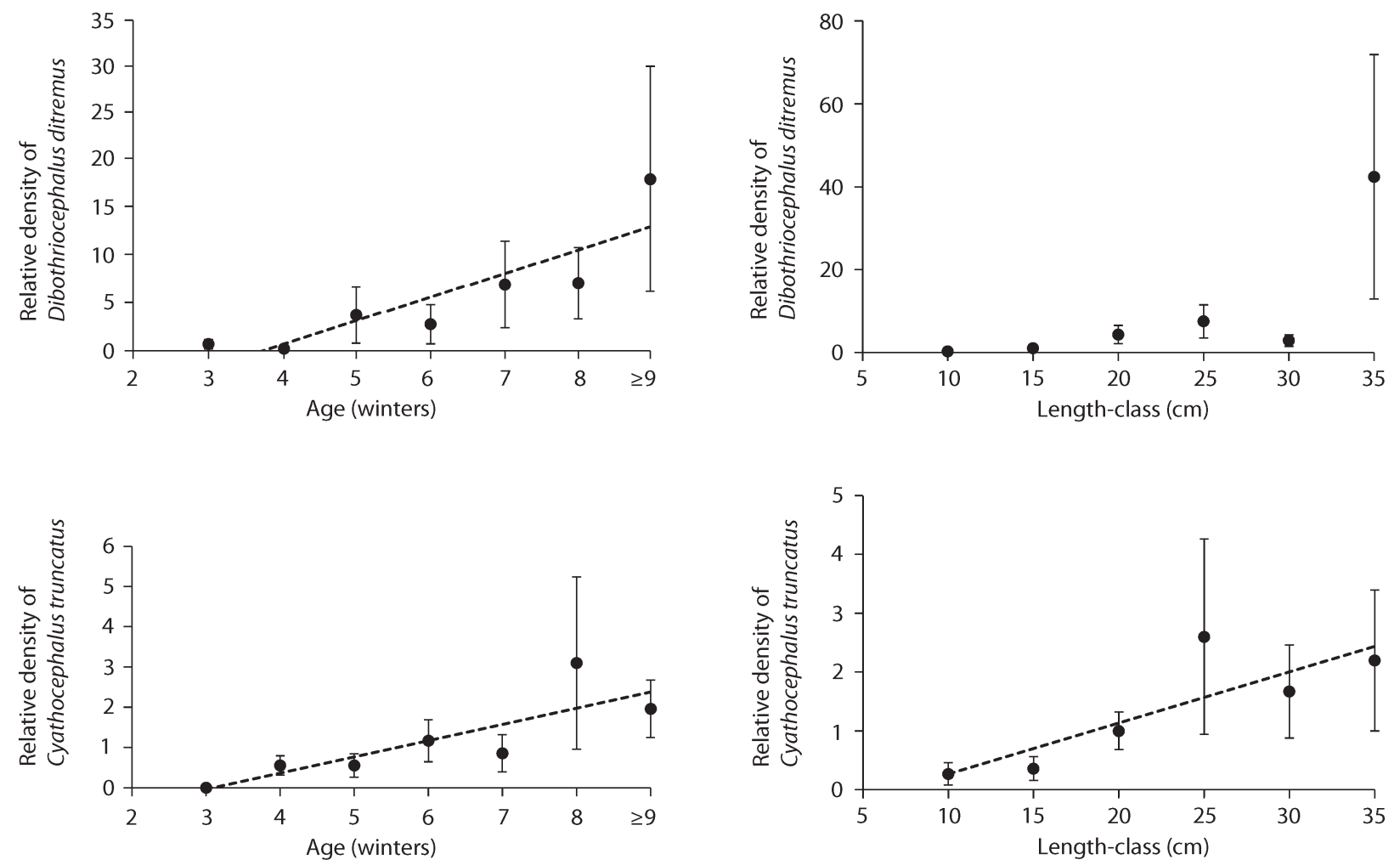

Figure 4. The relative density of the cestodes Dibothriocephalus ditremus and Cyathocephalus truncatus in the seven age-classes 3->9 winters, and six length-classes (from 10.0-14.9 cm to 35.0-39.9 cm) of brown trout sampled in the lake, Øvre Heimdalsvatn, in June, July, and September 2011.

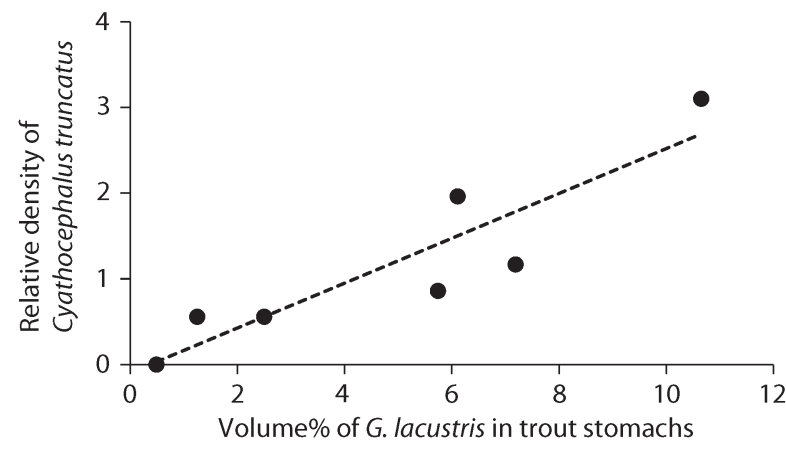

Figure 5. Mean volume \% of Gammarus lacustris in stomach contents of brown trout age-classes 3- $\geq 9$ winters, sampled in June, July, and September 2011, plotted against relative density of Cyathocephalus truncatus.

relationship between age-classes (3- $\geq 9)$ and relative density of Diplostomum sp. was significant (linear regression, $\mathrm{R}^{2}=0.84, \mathrm{df}=6$, $\mathrm{F}=26.68, \mathrm{p}<0.05)$. Likewise, there was a significant relationship between length and the relative density of this species (linear regression: $\left.\mathrm{R}^{2}=0.70, \mathrm{df}=5, \mathrm{~F}=9.54, \mathrm{p}<0.05\right)$ (Figure 6).

\section{Phyllodistomum umblae}

The kidney fluke $P$. umblae was common in 2011, with a prevalence varying between 27.8 and $100 \%$ in the examined age-classes (Table 3). The mean and median intensity was however relatively low (Table 3). The relative density peaked in age-class 6 and 7, and in lengthclass 20.0-24.9 and 25.0-29.9 cm (Figure 6). There was no significant linear relationship between age-class/length-class and relative density of this species.

\section{Capillaria sp.}

The mean and median intensity of Capillaria sp. was low in all age- classes in 2011, but with highest intensities in age-class 11-15 winters, and with highest prevalence in age-class $7-8$ winters (Table 3 ).

\section{Discocotyle sagittata}

The only helminth species with a direct life cycle, D. sagittata, was common on the trout gills in 2011, with an increase in both prevalence and mean and median intensity with increasing age of the trout (Table 3). The positive linear regressions between age-classes/length classes and relative density, were both significant (age: $\mathrm{R}^{2}=0.89, \mathrm{df}=6$, $F=40.78, p<0.01$; length: $R^{2}=0.67, d f=5, F=8.36, p<0.05$ ) (Figure 6).

\section{DISCUSSION}

When compared to the study performed by Lien (1976), the helminth species composition in brown trout in the lake, Øvre Heimdalsvatn, was almost unchanged from 1969-72 to 2011 (Table 4). However, the relative densities (abundance) of some species have changed markedly. The most obvious differences are the substantial increase in D. ditremus and Diplostomum sp., i.e., two species which have birds as their final hosts. Some species have had a marked decrease in relative density, especially Crepidostomum spp., but also C. truncatus and Proteocephalus sp. The other species, P. umblae, D. sagittata, and Capillaria sp. did not show any marked differences in occurrence between 1969-72 and 2011, except the substantial decrease of $P$. umblae in the youngest trout (Table 4).

For parasite species of fish which are transmitted by ingestion of infected invertebrates, there seems to be a close association between infection intensity of a specific species and consumption of the corresponding intermediate host (Knudsen 1995; Knudsen et al. 1996). Differences in parasite community structure and abundance may therefore be closely related to differences in food niches of fish (Knudsen et al. 1997). It may therefore be instructive to relate changes 

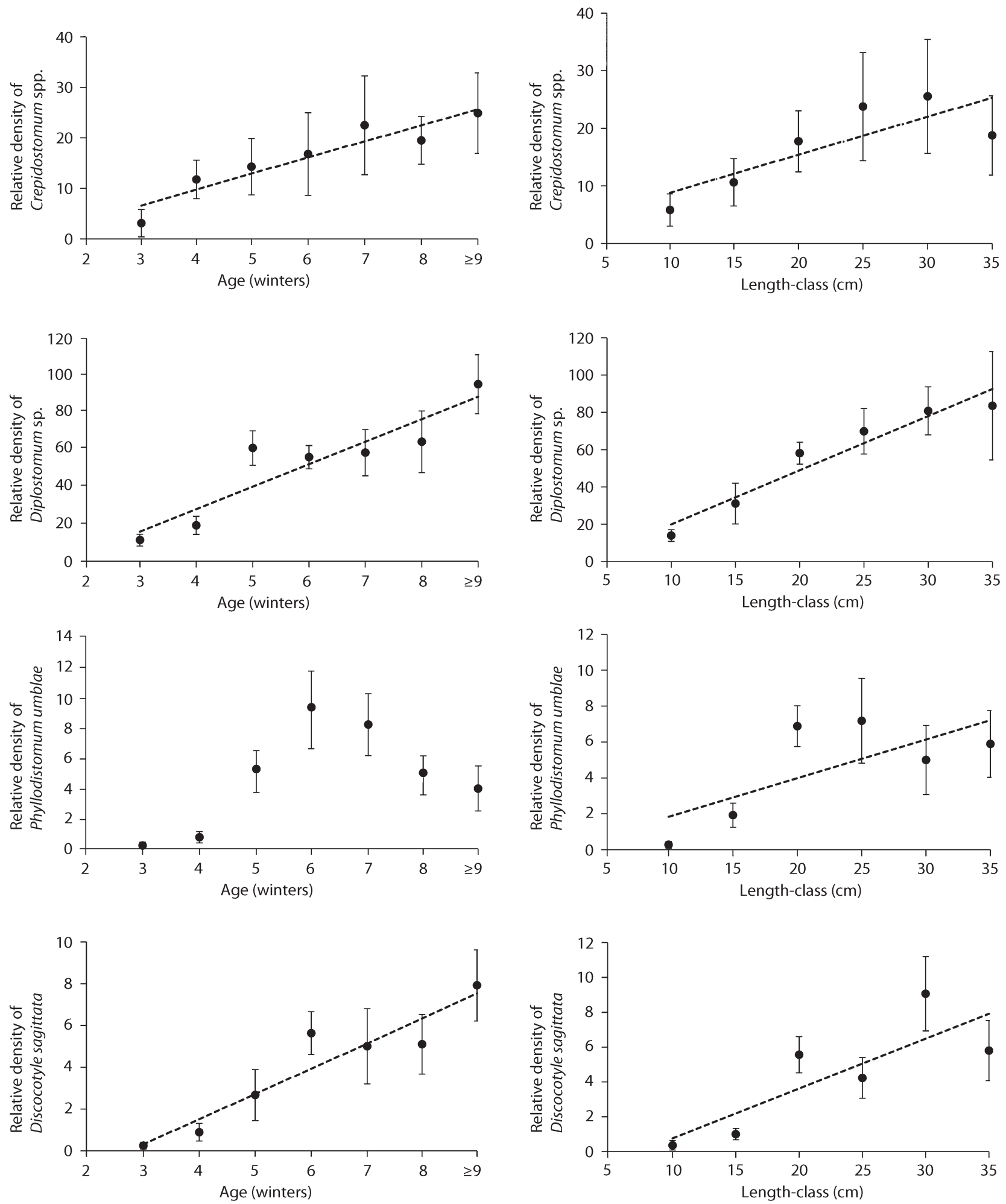

Figure 6. The relative density of Crepidostomum spp., Diplostomum sp., Phyllodistomum umblae, and Discocotyle sagittata in the seven age-classes (3- $\geq 9$ winters), and in six length-classes (from $10.0-14.9 \mathrm{~cm}$ to $35.0-39.9 \mathrm{~cm}$ ) of brown trout sampled in the lake, Øvre Heimdalsvatn, in June, July, and September 2011.

in parasite abundance in brown trout in the lake Øvre Heimdalsvatn to possible changes in abundance of infected intermediate hosts, in addition to changes in the fish community and the number of piscivorous birds foraging in the lake. Several of these factors may affect the parasite abundance of brown trout in this lake. The brown trout summer diet changed considerably between the period 1969-72 and the years previous to 2011, with a major decline in L. arcticus, and with fish becoming an important part of trout diet, mainly European minnow but also brown trout (Lien 1978; Borgstrøm et al. 2010). Both brown trout and European minnow were completely absent from trout diet during the years 1969-72 despite extensive sampling throughout the year (Lien 1978).

The most striking change in infection was the increased occurrence of $D$. ditremus, a species which was almost absent from brown trout in the lake during the period 1969-72, whereas in 2011 it was found in fish within all age-classes (Table 4), and with very high numbers 
in some older fish. This was also documented in a follow-up study in 2012 (Borgstrøm et al. 2017). D. ditremus has copepods and salmonids as first and second intermediate hosts, respectively, with fish-eating birds as final hosts (Henricson 1977; Andersen \& Gibson 1989). Copepods were more or less absent in brown trout summer diet, both in 1969-72 (Lien 1978) and 2011. In late autumn 1969-72, however, copepods were part of the diet (Lien 1978), and copepods were found in summer diet of small brown trout $(8.0-15.9 \mathrm{~cm})$ in 1996 as well (Museth et al. 2010). Seasonal and annual variations in copepod feeding and thereby variations in infection pattern might therefore occur. Nevertheless, during the years 1969-72 when brown trout had copepods as part of their diet, the relative density of $D$. ditremus was zero in age-classes $3-6$, and only 0.1 in older brown trout, indicating that the frequency of infected copepods in the diet had been very low compared to the situation in 2011. The very high numbers of D. ditremus in some older fish indicate a feeding specialization on copepods, as seen in Arctic charr (Knudsen et al. 1996). Alternatively, the high numbers of $D$. ditremus in single fish may be caused by piscivory. If an infected brown trout is eaten by a piscivorous conspecific, the plerocercoids may survive and re-establish in the new intermediate host. Cannibalism seems, however, to be seldom in Øvre Heimdalsvatn, with only 1.4 brown trout juveniles (with length around $10 \mathrm{~cm}$ ) recorded per 100 examined brown trout stomachs in the period 1993-2005 (Borgstrøm et al. 2010). In Arctic charr, large and old individuals are often heavily infected by $D$. ditremus (Hammar 2000; Borgstrøm et al. 2015), most likely due to cannibalism. In the small lake, Nordre Borgdam, Spitsbergen, one individual was infected with around 2000 plerocercoids of $D$. ditremus, and at the same time the large individuals were cannibals (Borgstrøm et al. 2015), thus indicating a possible transfer of larvae from charr to charr. Similar transmissions may occur from trout to trout as well, although it has been demonstrated that $D$. ditremus has a poor ability to re-establish in fish (Halvorsen \& Wissler 1973). In 2011, young brown trout (age-class 3-4) in Øvre Heimdalsvatn had a low relative density of $D$. ditremus, and most examined small fish were uninfected, and accordingly, the very high number of $D$. ditremus plerocercoids in some large brown trout is hard to explain by cannibalism. There is however a third possibility of transfer from copepods to brown trout; European minnow in the lake also feed on copepods (Museth et al. 2010), and the piscivorous trout might obtain D. ditremus by consumption of minnows which have infected copepods in their stomachs. In addition, predation on minnows in the lake Øvre Heimdalsvatn is substantial and seems to be a major mortality factor for sexually mature European minnow (Museth et al. 2003).

According to Lien (1981) the number of European minnows $>65 \mathrm{~mm}$ was 14,500 and 23,000 in 1977 and 1978, respectively. In 1999 and 2000, the estimated number had increased to 89,000 and 35,000, respectively (Museth et al. 2002). During the initial phase of European minnow population build-up, in the years 1969-72, the population number was probably much lower than even in 1977-78. The large population increase in minnows may have made the lake a more favourable foraging locality for fish-eating birds. The frequent observations of the black-throated diver during the last decades before 2011 are in strong contrast to only two observations during the years 1968-72 (Lien \& Nydal 1973). Observations of mergansers have also increased, with nesting in the proximity of the lake. The increased numbers of these fish-eating birds may thus have contributed to the present high infection intensities of $D$. ditremus in brown trout, by an increased production of Dibothriocephalus eggs ending up in the lake via bird faeces.

Likewise, the increased number of fish-eating birds in Øvre
Heimdalsvatn may also have affected the abundance of the eyefluke, Diplostomum sp. in brown trout. The relative density was considerably higher in all year-classes compared to 1969-72 (Table 4), with especially high infection intensities in old fish. Fish-eating birds are the final hosts, while the snail species, Radix spp., and a variety of fish are first and second intermediate hosts of Diplostomum spp., respectively (Palmieri et al. 1976). R. balthica is the only suitable first intermediate host in Øvre Heimdalsvatn, and it is mainly located in the shallow part of the lake, although it can be found sporadically at all depths (Brittain 1978). Both brown trout and European minnow may serve as intermediate hosts for Diplostomum species (Kennedy 1974), and through the establishment of European minnow in the lake, the abundance of secondary intermediate hosts has increased considerably since 1969-72 (Museth et al. 2002). Buck \& Lutterschmidt (2017) studied metacercarial abundance of a trematode parasite (Posthodiplostomum minimum Dubois, 1936) in two species of centrarchid fishes (Bluegill Lepomis macrochirus Rafinesque, 1819 and redbreast sunfish L. auritus (Linnaeus, 1758)), and they found that host density was negatively associated with parasite abundance, i.e., a demonstration of an encounter-dilution effect. With the presence of minnows in the lake, Øvre Heimdalsvatn, the number of 'targets' (intermediate hosts) for Diplostomum cercariae will have increased manifold, leading to a possible dilution of the metacercaria encountering each intermediate host, including brown trout, thereby giving a reduced abundance of metacercaria in the brown trout. However, we found the opposite, a marked increase in infection intensity compared with the historical data (Table 4). This increase can be explained both by the increase in number of bird hosts foraging in the lake, and by an increased availability of infected fish. Metacercariae of Diplostomum may reduce the vision of fish by inducing cataract formation (Karvonen et al. 2004), which may alter fish escape responses and crypsis, and also change the shoaling behaviour of infected fish (Seppälä et al. 2008). European minnows typically display such shoaling behaviour. Reduced shoaling of Diplostomum -infected fish may predispose them to predation by birds, and thus provide a potential mechanism to enhance the transmission of the parasite to its final hosts, as suggested by Seppälä et al. (2008) in a study of rainbow trout (Oncorhynchus mykiss (Walbaum, 1792)) infected by D. spathaceum. In this way, the establishment of a large population of European minnow in the lake Øvre Heimdalsvatn, may have facilitated the transmission of metacercariae from fish to the final hosts, also over-ruling the effect of a possible transmissiondilution, resulting in more egg-producing individuals of Diplostomum sp. in the fish-eating birds.

The occurrence of Diplostomum sp. in brown trout in Øvre Heimdalsvatn showed a significant positive relationship with age and length of fish, which may be due to exposure to infection over time, as well as a larger body surface of older fish, increasing both contact and penetration possibility for the cercariae of Diplostomum sp. Free-living cercariae penetrate the skin or gills of fish (Karvonen et al. 2003), and since older fish may have been exposed for a longer time, the infection may build up. The free-swimming cercariae do not actively search for hosts, but they are often found in concentrations around infected snails (Karvonen et al. 2003), and risk of infection is therefore highest in littoral areas.

In contrast to the increased occurrence of $D$. ditremus and Diplostomum sp., the mean intensity of Crepidostomum spp. was substantially lower in all age-classes of brown trout relative to 1969 72 (Table 4), indicating a decreased intake of infected intermediate hosts. Fitzgerald \& Mulcahy (1983) found the highest occurrence of these species during winter - early spring, and the lowest during 
midsummer. Crepidostomum spp. have Radix and Pisidium as first intermediate hosts, mayflies (Ephemeroptera) and amphipods (Gammarus) as second intermediate hosts, and trout as a final host (Awachie 1968; Petkevičiūtè et al. 2018). In a study from North Wales, Awachie (1968) found Radix peregra (Müller, 1774) as the first intermediate host of $C$. metoecus, the most numerous of the two Crepidostomum species infecting brown trout in Øvre Heimdalsvatn, and Gammarus pulex (Linnaeus, 1758) was described as the second intermediate host. Petkevičiūte et al. (2018) referred however to a study where Pisidium was recorded as the first intermediate host, and nymphs of the mayfly genus Ameletus Eaton, 1865 as second intermediate host of $C$. metoecus. Thus, most probably several species of molluscs, gastropods, and mayflies are candidates for first or second intermediate hosts of the Crepidostomum species. The cercariae emerge from the first intermediate hosts and penetrate mayfly nymphs or amphipods, which in turn must be eaten by trout to complete their life cycle. Since Crepidostomum spp. might survive about one year in its final host (Thomas 1958), the significant relationship between age-class/length-class and relative density of Crepidostomum in brown trout from Øvre Heimdalsvatn in 2011 is probably a reflection of the total consumption of intermediate hosts related to fish size. The density of the trout population in Øvre Heimdalsvatn has changed little (Borgstrøm et al. 2010), and a change in abundance of Crepidostomum spp. in brown trout is most likely due to changes in densities of one or more of the invertebrate intermediate hosts. These intermediate hosts serve as important food items not only for brown trout but also for European minnow (Museth et al. 2010), and with establishment of a large minnow population, the total predation pressure may have increased, resulting in reduced availability of intermediate hosts. According to Næstad \& Brittain (2010) the density of G. lacustris declined considerably in the littoral zone of Øvre Heimdalsvatn between 1972 and 2000. Mayflies on the other hand had a higher abundance in 2000 than in 1972, but their percentage composition had decreased considerably due to a marked increase in chironomids which had become by far the most dominant group of the total macroinvertebrate littoral fauna, also as a possible consequence of the minnow establishment in the lake (Næstad \& Brittain 2010). Mayflies were common in the brown trout summer diet in 1969-1972 (Lien 1978), but this food item was infrequently found in the stomach contents of brown trout during the present study, an indication of a lower transfer of Crepidostomum spp. to brown trout.
Which of the intermediate host species that are involved in the life history of the Crepidostomum species in Øvre Heimdalsvatn is still an open question.

A change in availability of intermediate hosts (bivalves) may also explain the change in infection pattern of $P$. umblae. This species had its highest relative density in the youngest age-classes during 1969-72 (Table 4), while in 2011 the highest relative density was found in ageclass 6 winters (Table 4). Young brown trout in the lake have a habitat mostly confined to the shallow littoral where European minnow also occur (Museth et al. 2002). The large minnow population may have reduced the density of the intermediate hosts in this habitat, but not in deeper parts of the lake occupied by larger brown trout.

Cyathocephalus truncatus is another species which has the amphipod, G. lacustris, as its intermediate host, and fish as the final host (Vik 1958). Although a reduction in density of G. lacustris in the littoral of the lake has been documented (Næstad \& Brittain 2010), G. lacustris has still remained common in brown trout summer diet (Borgstrøm et al. 2010), as also documented in the present study. The infection pattern of $C$. truncatus is related to the seasonal consumption of G. lacustris (Amundsen et al. 2003), which also supports our finding in Øvre Heimdalsvatn, with a positive relationship between volume percent of G. lacustris in the stomach content of brown trout and the relative density of $C$. truncatus. The relative density of this species has nevertheless declined from the period 1969-71 (Table 4), indicating a reduced consumption of $G$. lacustris, however, the sampling months

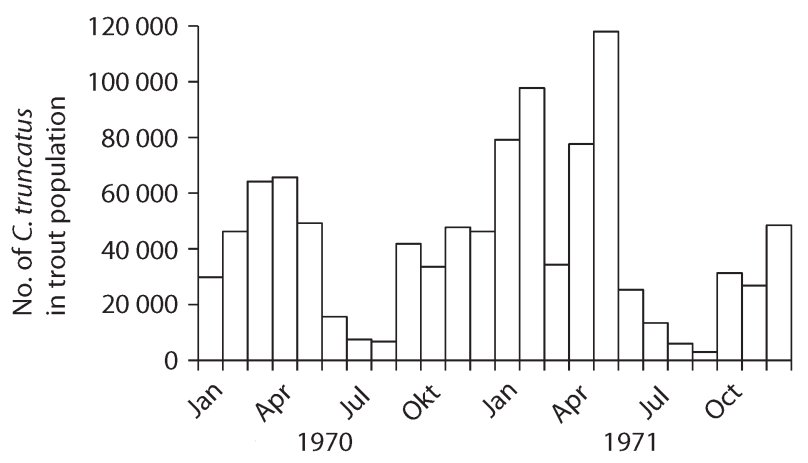

Figure 7. Estimated monthly number of Cyathocephalus truncatus in the brown trout population of the lake, Øvre Heimdalsvatn, from January 1970 to December 1971 (from Lien 1976).

Table 4. Summary of the helminth fauna of brown trout from the lake Øvre Heimdalsvatn, as relative density (abundance) of the different helminth species recorded in the age-classes 3-4, 5, 6, and $\geq 7$ winters in 1969-72 (Lien 1976), and in the present study from 2011. Numbers in parentheses represent total number of examined fish.

\begin{tabular}{|c|c|c|c|c|c|c|c|c|}
\hline \multirow[b]{2}{*}{ Helminth species } & \multicolumn{4}{|c|}{$\begin{array}{c}1969-1972 \\
\text { Age-class (winters) }\end{array}$} & \multicolumn{4}{|c|}{$\begin{array}{c}2011 \\
\text { Age-class (winters) }\end{array}$} \\
\hline & $\begin{array}{l}3-4 \\
(69) \\
\end{array}$ & $\begin{array}{c}5 \\
(84) \\
\end{array}$ & $\begin{array}{c}6 \\
(78) \\
\end{array}$ & $\begin{array}{l}\geq 7 \\
(98)\end{array}$ & $\begin{array}{l}3-4 \\
(22)\end{array}$ & $\begin{array}{c}5 \\
(16) \\
\end{array}$ & $\begin{array}{c}6 \\
(15) \\
\end{array}$ & $\begin{array}{l}\geq 7 \\
(59)\end{array}$ \\
\hline Discocotyle sagittata & 0.5 & 1.7 & 2.4 & 4.7 & 0.6 & 2.6 & 5.6 & 6.8 \\
\hline Phyllodistomum umblae & 13.7 & 10.8 & 9.2 & 6.3 & 0.6 & 5.2 & 9.3 & 5.0 \\
\hline Crepidostomum spp. (two species) & 147.0 & 229.0 & 234.0 & 233.0 & 11.2 & 16.7 & 18.9 & 26.5 \\
\hline Diplostomum sp. & 12.0 & 10.8 & 5.9 & 17.2 & 17.0 & 59.6 & 54.8 & 78.4 \\
\hline Proteocephalus sp. & 13.5 & 11.8 & 11.4 & 7.8 & 0.1 & 0.0 & 0.5 & 0.9 \\
\hline Cyathocephalus truncatus & 3.1 & 4.9 & 7.3 & 9.7 & 0.3 & 0.6 & 1.2 & 2.0 \\
\hline Dibothriocephalus ditremus & 0.0 & 0.0 & 0.0 & 0.1 & 0.5 & 4.1 & 3.0 & 13.7 \\
\hline Dibothriocephalus dendriticus & 0.0 & 0.0 & 0.0 & 0.0 & 0.0 & 0.0 & 0.0 & 0.02 \\
\hline Capillaria sp. & 1.1 & 1.6 & 0.8 & 0.6 & 0.2 & 0.9 & 0.9 & 1.0 \\
\hline Eustrongylides sp. & 0.0 & 0.0 & 0.0 & 0.01 & 0.0 & 0.0 & 0.0 & 0.0 \\
\hline
\end{tabular}


have to be considered, especially because $C$. truncatus spend only a few months in its final host (Vik 1958). The seasonal infection pattern of $C$. truncatus in 1970-71, with low abundance during the summer months June - August (Figure 7) may indicate a higher loss of the parasite during these months, or a lower consumption of G. lacustris, and the results from 2011 are consequently not directly comparable with the 1969-72 data.

The monogenean, Discocotyle sagittata, the only recorded species with a direct life history without intermediate hosts, had nearly the same relative density in 2011 as in 1969-72 (Table 4). In contrast to $C$. truncatus, this monogenean has a temperature dependent transmission (Rubio-Godoy \& Tinsley 2008), and the species is therefore able to reproduce and transmit most effectively during the warmer months. During the period 1969-72, samples were taken throughout the year (Lien 1976), whereas the present study was confined to the summer months. The somewhat higher relative density of $D$. sagittata in 2011 may therefore be due to the sampling procedure for this species as well. However, the density of old (and large) brown trout has been considerably higher in the years previous to 2011 compared to the years previous to 1969-72 (Jensen 1977; Borgstrøm et al. 2010). The positive relationship between age and length of brown trout and number of $D$. sagittata, together with a higher abundance of large fish, may therefore result in an increased production of larvae, and thereby also an increased infection pressure.

The apparent decrease in the abundance of Proteocephalus sp. (Table 4), may likewise be related to the seasonal occurrence, with low infection intensity in brown trout during the summer months, as documented by Lien \& Borgstrøm (1973), suggesting that the low numbers of Proteocephalus sp. (similar to C. truncatus) present during the summer of 2011 was mainly due to the loss of worms in spring - early summer.

Temperature may greatly influence development and transmission of parasite species, such as Diplostomum sp. (Hakalahti et al. 2006). An increase in annual mean temperatures in Norway from the 1960s to 2010 (Hanssen-Bauer et al. 2017) may indicate a general temperature increase during the summer months in the lake Øvre Heimdalsvatn. However, the long-term development in mean June August air temperatures, as measured at the nearest meteorological station (Skåbu), shows no increasing trend from the period 1969-72 to the period 2006-09 (https://seklima.met.no). With a high correlation between air temperatures at Skåbu metrological station and summer temperatures in the outlet river of Øvre Heimdalsvatn (Kvambekk and Melvold 2010), the observed changes in infection intensity and prevalence of Diplostomum sp., as well as other helminth species of brown trout in the lake, can hardly be related to changes in summer temperatures.

\section{CONCLUSIONS}

The long-term changes of the helminth fauna of brown trout in the lake Øvre Heimdalsvatn may be explained by factors influencing the life cycle of the different species, especially: (i) brown trout diet and the availability of invertebrate prey functioning as intermediate hosts, and (ii) density of fish-eating birds as final hosts for parasites with fish as an intermediate host. The most striking difference has been the substantial increase in infection intensities of the two species which have brown trout as an intermediate host and fish-eating birds as final hosts (Dibothriocephalus ditremus and Diplostomum sp.), and a marked decrease in others, especially the Crepidostomum species which have several invertebrates, including G. lacustris, mayflies, and molluscs, as intermediate hosts. These invertebrates also serve as important food items for both brown trout and European minnow, and with establishment of a large minnow population, the total predation pressure on invertebrates in the littoral area may have increased, resulting in reduced availability of intermediate hosts. Some of the parasite species show small changes in infection intensities, but due to known seasonal variations in occurrence, and sampling in 2011 restricted to the months June, July, and September, conclusions regarding long-term changes are not possible to draw for these species. The only helminth with a direct life cycle was the monogenean, Discocotyle sagittata. Since this species showed a positive relationship with trout size, the small increase in relative density may be related to a greater abundance of older and larger fish in 2011 compared to 1969-72, and thereby an increased reproduction success of this monogenean. In conclusion, changes in the lake ecosystem of Øvre Heimdalsvatn after establishment of the European minnow are likely to have played a decisive role in the observed changes in the parasite fauna of the brown trout.

\section{ACKNOWLEDGEMENTS}

Special thanks are given to Professor Philip D. Harris formerly at the Natural History Museum, University of Oslo, for help with the parasite identification, as well as his participation during part of the field work. We also acknowledge Professor Jan T. Lifjeld at the Natural History Museum, University of Oslo, for information regarding the bird fauna at Øvre Heimdalsvatn, and the Natural History Museum, University of Oslo, for permission to use the University's field station. We greatly acknowledge three anonymous referees for their constructive criticism and many suggestions for improving earlier versions of the manuscript.

\section{REFERENCES}

Amundsen PA, Knudsen R, Kuris AM, Kristoffersen R. 2003. Seasonal and ontogenetic dynamics in trophic transmission of parasites. Oikos 102: 285-293. doi: 10.1034/j.1600-0706.2003.12182.x

Andersen K, Gibson D. 1989. A key to three species of larval Diphyllobothrium Cobbold, 1858 (Cestoda: Pseudophyllidea) occurring in European and North American freshwater fishes. Systematic Parasitology 13: 3-9.

Awachie JBE. 1968. On the bionomics of Crepidostomum metoecus (Braun, 1900) and Crepidostomum farionis (Müller, 1784) (Trematoda: Allocreadiidae). Parasitology 58: 307-324.

Bakke TA. 1984. A redescription of adult Phyllodistomum umblae (Fabricius) (Digenea, Gorgoderidae) from Salvelinus alpinus (L.) in Norway. Zoologica Scripta 13: 89-99.

Bakke TA, Lien L. 1978. The tegumental surface of Phyllodistomum conostomum (Olsson, 1876) (Digenea), revealed by scanning electron microscopy. International Journal for Parasitology 8: 155-161. doi: 10.1016/0020-7519(78)90010-3

Borgstrøm R, Isdahl T, Svenning M. 2015. Population structure, biomass, and diet of landlocked Arctic charr (Salvelinus alpinus) in a small, shallow High Arctic lake. Polar Biology 38: 309-317. doi: 10.1007/ s00300-014-1587-6

Borgstrøm R, Museth J, Brittain J. 2010. The brown trout (Salmo trutta) in the lake, Øvre Heimdalsvatn: long-term changes in population dynamics due to exploitation and the invasive species, European minnow (Phoxinus phoxinus). Hydrobiologia 642: 81-91. doi: 10.1007/ s10750-010-0161-7

Borgstrøm R, Trømborg J, Haugen TO, Rosseland BO. 2017. Plerocercoids 
of the cestode Diphyllobothrium ditremum in brown trout Salmo trutta: substantial increase in infection after establishment of European minnow Phoxinus phoxinus. Journal of Fish Biology 91: 912-927. doi: 10.1111/jfb.13391

Brittain JE. 1978. The Mollusca of the exposed zone of Øvre Heimdalsvatn. Ecography 1: 229-231.

Brittain JE, Borgstrøm R. 2010a. The Norwegian reference lake ecosystem, Øvre Heimdalsvatn. Hydrobiologia 642: 5-12. doi: 10.1007/978-90481-9388-2_2

Brittain JE, Borgstrøm R (eds.). 2010b. The subalpine lake ecosystem, Øvre Heimdalsvatn, and its catchment: local and global changes over the last 50 years. Developments in Hydrobiology 211. Dordrecht. Springer. 126 p. doi: 10.1007/978-90-481-9388-2

Brittain JE, Borgstrøm R. 2015. Naturlige variasjoner versus menneskeskapte miljøendringer - hva viser lange tidsserier fra referansevannet Øvre Heimdalsvatn? Vann 50: 218-224.

Brittain JE, Borgstrøm R, Bremnes T, Håland S, Mjelde M, Nilssen JP, Skjelbred B. 2019. Øvre Heimdalsvatn - økologisk langtidsovervåking. Naturhistorisk museum, University of Oslo, Rapport nr. 84.64 pp. + attachment. ISSN nr. 1891-8050. ISBN nr. 978-82-7970-108-8.

Buck JC, Lutterschmidt WI. 2017. Parasite abundance decreases with host density: evidence of the encounter-dilution effect for a parasite with a complex life cycle. Hydrobiologia 784: 201-210. doi: 10.1007/ s10750-016-2874-8

Bykhovskaya-Pavlovskaya IE, Gusev AV, Dubinina MN, Izyumova NA, Smirnova TS, Sokolovskaya IL, Shtein GA, Shul'man SS, Epshtein VM. 1964. Key to Parasites of Freshwater Fish of the U.S.S.R. Jerusalem. Israel Program for Scientific Translations. 919 p.

Esch GW, Kennedy CR, Bush AO, Aho JM. 1988. Patterns in helminth communities in freshwater fish in Great Britain: alternative strategies for colonization. Parasitology 96: 519-532. doi: 10.1017/ S003118200008015X

Fitzgerald RD, Mulcahy MF. 1983. Parasites of salmon Salmo salar L. and trout Salmo trutta L. in the River Shournagh. Irish Fisheries Investigations Series A 23: 24-31.

Gozlan R, St-Hilaire S, Feist S, Martin P, Kent ML. 2005. Disease threat to European fish. Nature 435: 1046. doi: 10.1038/4351046a

Grøterud O, Kloster AE. 1978. Hypsography, meteorology and hydrology of the Øvre Heimdalen catchment. Ecography 1: 111-116.

Hakalahti, T, Karvonen A, Valtonen ET. 2006. Climate warming and disease risks in temperate regions - Argulus coregoni and Diplostomum spathaceum as case studies. Journal of Helminthology 80: 93-98. doi: 10.1079/JOH2006351

Hall SR, Mills EL. 2000. Exotic species in large lakes of the world. Aquatic Ecosystem Health \& Management 3: 105-135. doi: $10.1080 / 14634980008656995$

Halvorsen, O. 1970. Studies of the Helminth Fauna of Norway XV: On the taxonomy and biology of plerocercoids of Diphyllobothrium Cobbold, 1858 (Cestoda, Pseudophyllidea) from North-western Europe. Norwegian Journal of Zoology 18: 113-174.

Halvorsen O, Wissler K. 1973. Studies of the Helminth fauna of Norway XXVIII: An experimental study of the ability of Diphyllobothrium latum (L), D dendriticum (Nitzsch), and D. ditremum (Creplin) (Cestoda, Pseudophyllidea)" to infect paratenic hosts. Norwegian Journal of Zoology 21: 201-210.

Hammar J. 2000. Cannibals and parasites: conflicting regulators of bimodality in high latitude Arctic char, Salvelinus alpinus. Oikos 88: 33-47. doi: 10.1034/j.1600-0706.2000.880105.x

Hanssen-Bauer I, Førland EJ, Haddeland I, Hisdal H, Mayer S, Nesje A, Nilsen JEØ, Sandven S, Sandø AB, Sorteberg A, Ådlandsvik B. et al. 2017. Climate in Norway 2100 - a knowledge base for climate adaptation. The Norwegian Centre for Climate Services (NCCS) Report 1/2017.

Henricson J. 1977. The abundance and distribution of Diphyllobothrium dendriticum (Nitzsch) and D. ditremum (Creplin) in the char Salvelinus alpinus (L.) in Sweden. Journal of Fish Biology 11: 231-248. doi: 10.1111/j.1095-8649.1977.tb04116.x
Hesthagen T, Sandlund OT. 1997. Endringer i utbredelse av ørekyt i Norge: Årsaker og effekter. NINA Fagrapport, 013: 1-16.

Hoffman GL. 1999. Parasites of North American freshwater fishes. Ithaca and London. Cornell University Press. 539 p.

Hynes HBN. 1950. The food of fresh-water sticklebacks (Gasterosteus aculeatus and Pygosteus pungitius), with a review of methods used in studies of the food of fishes. Journal of Animal Ecology 19: 36-58.

Jensen K. 1977. On the dynamics and exploitation of the population of brown trout (Salmo trutta L.), in Lake Øvre Heimdalsvatn, southern Norway. Institute of Freshwater Research Drottningholm Report 56: $18-69$.

Karvonen A, Paukku S, Valtonen ET, Hudson P. 2003. Transmission, infectivity and survival of Diplostomum spathaceum cercariae. Parasitology 127: 217-224. doi: 10.1017/S0031182003003561

Karvonen A, Seppälä O, Valtonen ET. 2004. Eye fluke-induced cataract formation in fish: quantitative analysis using an ophthalmological microscope. Parasitology 129: 473-478. doi: 10.1017/ S0031182004006006

Karvonen A, Rintamäki P, Jokela J, Valtonen ET. 2010. Increasing water temperature and disease risks in aquatic systems. Climate change increases the risk of some, but not all, diseases. International Journal of Parasitology 40: 1483-1488. doi: 10.1016/j.ijpara.2010.04.015

Karvonen A, Kristjansson BK, Skulason S, Lanki M, Rellstab C, Jokela J. 2013. Water temperature, not fish morph, determines parasite infections of sympatric Icelandic threespine sticklebacks (Gasterosteus aculeatus). Ecology and Evolution 3: 1507-1517. doi: 10.1002/ece3.568

Kennedy CR. 1974. A checklist of British and Irish freshwater fish parasites with notes on their distribution. Journal of Fish Biology 6: 613-644. doi: 10.1111/j.1095-8649.1974.tb05104.x

Kloster AE. 1978. Physical and chemical properties of the waters of Øvre Heimdalen. Ecography 1: 117-123.

Knudsen R. 1995. Relationships between habitat, prey selection and parasite infection in Arctic charr (Salvelinus alpinus). Nordic Journal of Freshwater Research 71: 333-344.

Knudsen R, Kristoffersen R, Amundsen P-A. 1997. Parasite communities in two sympatric morphs of Arctic charr, Salvelinus alpinus (L.), in northern Norway. Canadian Journal of Zoology 75: 2003-2009. doi: 10.1139/z97-833

Knudsen R, Klemetsen A, Staldvik F. 1996. Parasites as indicators of individual feeding specialization in Arctic charr during winter in northern Norway. Journal of Fish Biology 48: 1256-1265. doi: 10.1111/ j.1095-8649.1996.tb01819.x

Kvambekk $\AA$, Melvold K. 2010. Long-term trends in water temperature and ice cover in the subalpine lake, Øvre Heimdalsvatn, and nearby lakes and rivers. Hydrobiologia 642: 47-60. doi: 10.1007/s10750-0100158-2

Larsson P, Brittain JE, Lien L, Lillehammer A, Tangen K. 1978. The lake ecosystem of Øvre Heimdalsvatn. Ecography 1: 304-320.

Lien L. 1976. Studies of the helminth fauna of Norway XXXV: Production of parasites of brown trout (Salmo trutta L.) from Øvre Heimdalsvatn, Norway. Contribution from the Norwegian IBP/PF. Available at: http:// hdl.handle.net/10852/82312

Lien L. 1978. The energy budget of the brown trout population of Øvre Heimdalsvatn. Ecography 1: 279-300.

Lien L. 1981. Biology of the minnow (Phoxinus phoxinus) and its interactions with brown trout (Salmo trutta) in Øvre Heimdalsvatn, Norway. Ecography 4: 191-200.

Lien L, Borgstrøm R. 1973. Studies of the helminth fauna of Norway. XXX: Distribution and seasonal occurrence of Proteocephalus sp. in brown trout (Salmo trutta) from southern Norway. Norwegian Journal of Zoology 21: 293-297.

Lien L, Nydal J. 1973. Fuglefaunaen i Øvre Heimdalsvatn, Øystre Slidre og Vågå 1968-1972. Fauna 26: 31-37.

Marcoliese DJ. 1995. The role of zooplankton in the transmission of helminth parasites to fish. Reviews in Fish Biology and Fisheries 5: 336-371. 
Margolis L, Esch GW, Holmes JC, Kuris AM, Schad GA. 1982. The use of ecological terms in parasitology (Report of an ad hoc committee of the American Society of Parasitologists). The Journal of Parasitology 68: 131-133. doi: $10.2307 / 3281335$

Moravec F. 1994. Parasitic nematodes of freshwater fishes of Europe. Dordrecht. Kluwer Academic Publications. 470 p. ISBN 0792321723.

Moravec F. 2002. External morphological differences between Crepidostomum farionis and Crepidostomum metoecus (Trematoda: Allocreadiidae), parasites of salmonids, as revealed by SEM. Folia Parasitologica 49: 211-216.

Museth J, Borgstrøm R, Brittain J. 2010. Diet overlap between introduced European minnow (Phoxinus phoxinus) and young brown trout (Salmo trutta) in the lake, Øvre Heimdalsvatn: a result of abundant resources or forced niche overlap? Hydrobiologia 642: 93-100. doi: 10.1007/ s10750-010-0162-6

Museth J, Borgstrøm R, Brittain JE, Herberg I, Naalsund C. 2002. Introduction of the European minnow into a subalpine lake: habitat use and long-term changes in population dynamics. Journal of Fish Biology 60: 1308-1321. doi: 10.1111/j.1095-8649.2002.tb01722.x

Museth J, Borgstrøm R, Hame T, Holen LÅ. 2003. Predation by brown trout: a major mortality factor for sexually mature European minnows. Journal of Fish Biology 62: 692-705. doi: 10.1046/j.00221112.2003.00059.x

Museth J, Hesthagen T, Sandlund OT, Thorstad E, Ugedal O. 2007. The history of the minnow Phoxinus phoxinus (L.) in Norway: from harmless species to pest. Journal of Fish Biology 71: 184-195. doi: 10.1111/j.1095-8649.2007.01673.x

Næstad F, Brittain J. 2010. Long-term changes in the littoral benthos of a Norwegian subalpine lake following the introduction of the European minnow (Phoxinus phoxinus). Hydrobiologia 642: 71-79. doi: 10.1007/ s10750-010-0160-8

Palmieri JR, Heckmann RA, Evans RS. 1976. Life cycle and incidence of Diplostomum spathaceum Rudolphi (1819) (Trematoda: Diplostomatidae) in Utah. Great Basin Naturalist 36: 86-96.

Petkevičiūtė R, Stunžènas V, Zhokhov AE, Poddubnaya LG, Stanevičiūte G. 2018. Diversity and phylogenetic relationships of European species of Crepidostomum Braun, 1900 (Trematoda: Allocreadiidae) based on rDNA, with special reference to Crepidostomum oschmarini Zhokhov \& Pugacheva, 1998. Parasites Vectors 11, 530. doi: 10.1186/s13071-018-3095-y

Power G. 1978. Fish population structure in Arctic lakes. Journal of Fisheries Research Board of Canada 35: 78-111. doi: 10.1139/f78-008

Rubio-Godoy M, Tinsley RC. 2008. Transmission dynamics of Discocotyle sagittata (Monogenea) in farmed rainbow trout interpreted from parasite population age structure. Aquaculture 275: 34-41. doi: 10.1016/j.aquaculture.2007.12.023

Saltveit S, Brabrand Å. 1991. Ørekyt: en litteraturoversikt om økologi og utbredelse i Norge. Report Freshwater Ecology and Inland Fisheries Laboratory, Natural History Museum, University of Oslo 130: 1-21.

Seppälä O, Karvonen A, Valtonen ET. 2008. Shoaling behaviour of fish under parasitism and predation risk. Animal Behaviour 75: 145-150. doi: 10.1016/j.anbehav.2007.04.022

Thomas JD. 1958. Studies on Crepidostomum metoecus (Braun) and $C$. farionis (Müller), parasitic in Salmo trutta L. and S. salar L. in Britain. Parasitology 48: 336-352. doi: 10.1017/s0031182000021296

Vik R. 1958. Studies of the helminth fauna of Norway II. Distribution and life cycle of Cyathocephalus truncatus (Pallas, 1781) (Cestoda). Nytt Magasin for Zoologi 6: 97-110.

Vik R. 1964. Studies of the helminth Fauna of Norway. V. Plerocercoids of Diphyllobothrium spp. from the Rossåga water system, Nordland County. Norwegian Journal of Zoology 12: 1-9.

Vik R. 1978. The lake Øvre Heimdalsvatn - a subalpine freshwater ecosystem: Introduction. Ecography 1: 84-88.

Welcome RL. 1988. International introductions of inland aquatic species. FAO Fisheries Technical Paper 294: 1-318.

Waeschenbach A, Brabec J, Scholz T, Littlewood DTJ, Kuchta R. 2017.
The catholic taste of broad tapeworms - multiple routes to human infection. International Journal for Parasitology 47: 831-843. 10.1016/j. ijpara.2017.06.004

Editorial responsibility: Jan Grimsrud Davidsen.

This article is open-access and distributed under the terms of the Creative Commons Attribution 4.0 International license. This permits all noncommercial use, distribution, and reproduction in any medium, provided the original work is properly cited.

(http://creativecommons.org/licenses/by/4.0/). 